\title{
Study of adolescent clinic: holistic approach for women health with dual client methodology
}

\author{
Vishma H. Shetty* \\ Department of Obstetrics and Gynecology, Rajarajeswari Medical College and Hospital Kambipura, Mysore Road,
} Bangalore, Karnataka, India

Received: 25 June 2019

Accepted: 31 July 2019

*Correspondence:

Dr. Vishma H. Shetty,

E-mail: vishmashetty@yahoo.com

Copyright: ( $)$ the author(s), publisher and licensee Medip Academy. This is an open-access article distributed under the terms of the Creative Commons Attribution Non-Commercial License, which permits unrestricted non-commercial use, distribution, and reproduction in any medium, provided the original work is properly cited.

\begin{abstract}
Background: The study is done to understand the gynaecological problems in adolescent girls. Do counseling, imparting knowledge for the girl and her mother, hence creating a holistic approach towards the women health in the family by dual client approach.

Methods: 400 adolescent girls attending the clinic were studied (prospective observational study). $\mathrm{Hb} \%$, S.TSH was done for all the girls. Ultrasonography abdomen and pelvis was done on patient basis. Treatment was given. Mothers were counseled regarding their gynecological issues and screening tests (pap smear, self breast examination) was done after taking consent.

Results: $70 \%$ girls had menstrual disturbances, $20 \%$ had complains of vaginal discharge. $44 \%$ had anemia (4\% had severe anemia). Subclinical hypothyroidism was detected in $8 \%$ of cases. Ultrasonography was done in $52 \%$ of cases in which 81 patients had features suggestive of polycystic ovaries. $85.5 \%$ of the adolescent girls were accompanied by their mothers. $12 \%$ girls took HPV vaccination and $52 \%$ mothers underwent pap smear.

Conclusions: Teenage problems need to be dealt very sensitively. Counseling is an integral component of treatment strategies. At present, adolescent gynaecology remains an area to which increased awareness and greater attention should be given to promote the health of teenagers and incult healthy lifestyle practices. In the same set up even the mothers of girls can be given counseling and address their gynaecological issues as majority of times mothers are the accompanying person creating the dual client approach in one setting. Hence adolescent clinic should aim for holistic, dual client approach for improvement of overall women health in the family.
\end{abstract}

Keywords: Adolescent gynaecology, Adolescent clinic, Holistic, Dual client

\section{INTRODUCTION}

The term Adolescence is derived from the Latin term "adolescere" which means "to grow up". It is a transitional stage of physical and mental human development that occurs between childhood and adulthood. This transition changes involve biological (i.e. pubertal), social, sexual as well as psychological. According to WHO "adolescents" are the individuals in the 10-19 years age group. The adolescents constitute quarter of the population of India. Needless to mention that healthy Adolescents are the backbone and foundation of healthy mothers and they are the ultimate future of the society. Adolescent age group is generally considered to be healthy without any morbidity. But adolescent age group health has its own unique health risks, challenges and vulnerability which is strongly determined by developmental (biological) and socio-cultural factors.

Pediatric and adolescent gynecology (PAG) is an evolving field that intersects the fields of pediatrics, dermatology, urology, endocrinology, surgery, oncology, 
psychiatry, genetics and physical therapy. ${ }^{1}$ Common adolescent concerns include - Pubertal issues like adolescent growth and development, pubertal delay or precocity, weight and height issues sexual and reproductive health like gynecological and menstrual problems, contraception, pregnancy testing and option of MTP, STD/HIV Screening counseling and treatment and psycho-social issues like adjustment problems, growingup issues, depression, anxiety, bipolar, personality disorder and substance abuse including tobacco and alcohol.

Adolescents take time for the maturation of HPO axis after menarche, which can lead to anovulation. Anovulation causes approximately $95 \%$ of dysfunctional uterine bleeding in adolescents. In the initial assessment it has to be determined which adolescent needs treatment and which can be observed until the maturation of the HPO axis. If there is no anemia and the menstrual flow is only slightly to moderately increased, observation is desired. Adolescents can also present with chronic pelvic pain, and most possible etiology being endometriosis. ${ }^{1}$ Unsafe abortion and sexually transmitted infections were some of the other problems of adolescent girls. ${ }^{2}$ Pregnancy in teenagers is a problem threatening the ultimate reproductive and child health. These girls often do not have safe sex and are vulnerable to sexually transmitted diseases. ${ }^{3}$

The well known barriers to access of services are related to their personal issues related to shyness; need to deal with shame and embarrassment in disclosing their problems and healthcare provider's unsupportive and judgmental attitude. Within the context of changing social scenario, the need of the hour is to not only to generate awareness amongst the young generation but also to ensure that they have the choice to seek the desired health services in a non-judgmental and friendly environment when in need thus creating adolescent friendly health services. ${ }^{4,5}$

The guidelines have been laid for adolescent friendly health clinic by National Project of the Adolescent Health Committee FOGSI in accordance with the Government of India guidelines in consultation with WHO. In addition to imparting such education to the teenage girls and teachers, extending it to their family members, especially mothers, will be a blessing in disguise. ${ }^{6}$ Under NHM Adolescent Friendly Health Clinics (AFHCs) are established through which counseling and curative services are provided at primary, secondary and tertiary levels of care on fixed days and fixed time with due referral linkages. ${ }^{2}$

Commodities such as Iron and Folic acid tablets and nonclinical contraceptives are also made available in the clinics for the adolescents. To make the clinics adolescent friendly, states have branded the clinics in the name of 'Maitri' in Maharashtra, 'Udaan' in Uttrakhand, 'Sneha' in Karnataka and so on. The objective of it being addressing the stigma behind accessing the adolescent services.

An objective of this study was to study the gynaecological problems and its management in adolescent girls.

To do counseling, imparting knowledge for the girl about the physiology of female reproductive system, menstrual hygiene and lifestyle modifications. To do counseling for screening tests and treating any gynecological problems if any for the mother accompanying the teenager. Thus creating a holistic approach towards the women health in the family with dual client approach.

\section{METHODS}

The study was conducted in the adolescent clinic of Rajarajeswari Medical College and Hospital, Bangalore. Total 400 adolescent girls were included in the study. The study period was between January 2018-December 2018. The study is observational prospective study. 400 adolescent girls were included in the study. History taken and general physical examination done. $\mathrm{Hb} \%$, S.TSH done for all the girls. Ultrasonography abdomen and pelvis done on patient basis. Treatment given if required. Mothers accompanying the teenager were counselled regarding their gynaecological issues if any and screening tests (pap smear, self breast examination) Holistic approach with dual client methodology.

Adolescent girls management of gynaecological problems counseling towards lifestyle modifications, reproductive physiology mothers screening for cancer cervix and breast pathology hence overall improving female health in the family. Counseling and curative services counseling services for adolescent nutrition, puberty, RTI/STI prevention and contraception and delaying marriage and child bearing counseling on nutrition, menstrual disorders, personal hygiene, menstrual hygiene, use of sanitary napkins, use of contraceptives, sexual concerns, depression, sexual abuse, gender violence, substance misuse and promoting healthy behaviour to prevent non communicable diseases.

\section{Inclusion criteria}

- The Adolescent girls 10-19 years.

\section{Exclusion criteria}

- Teenage pregnancies

- Victims of sexual violence.

\section{Statistical analysis}

The study was a prospective study, Data entered into Microsoft Excel and analyzed using descriptive statistics like percentages. 


\section{RESULTS}

The main presenting symptoms were menstrual disturbances followed by vaginal discharge (Table 1).

Table 1: Gynaecological problems of adolescents attending adolescent clinic.

\begin{tabular}{|l|l|}
\hline Problems & $\mathbf{N}=400$ \\
\hline Menstrual disturbances & $280(70 \%)$ \\
\hline Dysmenorrhea & $224(56 \%)$ \\
\hline Irregular cycles & $96(24 \%)$ \\
\hline Amenorrhea with AUB & $48(12 \%)$ \\
\hline Vaginal discharge & $80(20 \%)$ \\
\hline Primary amenorrhea & $8(2 \%)$ \\
\hline Pain abdomen & $82(21 \%)$ \\
\hline Queries & $92(23 \%)$ \\
\hline Overweight $(\mathrm{BMI}>25)$ & $128(32 \%)$ \\
\hline
\end{tabular}

All the girls underwent haemoglobin estimation and serum TSH. $40 \%$ had anaemia (Table 2).

Table 2: Investigations done.

\begin{tabular}{|ll|}
\hline Investigations & $\mathbf{N}=400$ \\
\hline Hemoglobin \% Normal & $239(60 \%)$ \\
\hline Anaemia & $161(40 \%)$ \\
\hline Severe & $17(4 \%)$ \\
\hline Moderate & $53(13 \%)$ \\
\hline Mild & $91(23 \%)$ \\
\hline Serum TSH normal & $355(89 \%)$ \\
\hline Subclinical hypothyroidism & $31(8 \%)$ \\
\hline Hypothyroidism & $14(3.5 \%)$ \\
\hline Ultrasonography & $206(52 \%)$ \\
\hline Normal & $60(15 \%)$ \\
\hline Polycystic ovaries & $81(20 \%)$ \\
\hline Ovarian cyst & $35(8.5 \%)$ \\
\hline Simple ovarian cyst & $17(4 \%)$ \\
\hline Hemorrhagic ovarian cyst & $10(2.5 \%)$ \\
\hline Endometriosis & $5(1 \%)$ \\
\hline Dermoid cyst & $3(1 \%)$ \\
\hline Renal calculi & $22(5.5 \%)$ \\
\hline Primary amenorrhea & $8(2 \%)$ \\
\hline
\end{tabular}

$85.5 \%$ girls were accompanied by their mothers. All were counselled for HPV vaccination and $12 \%$ of girls took the vaccine (Table 3 ).

Dysmenorrhea was treated symptomatically with antispasmodics. 20 patients required blood transfusion remaining were given haematinics. Anthelminthics were prescribed for all the girls. Hormonal therapy for AUB was started for 26 girls and remaining was counselled. Primary amenorrhea patients were subjected for further investigations for identifying the etiology. 1 patient underwent vaginoplasty. Thyroxine supplementation was started in girls with hypothyroidism. 5 patients underwent laparoscopy for dermoid and endometriosis. Ultrasonography abdomen and pelvis was done in $52 \%$ of girls. Most common finding being polycystic ovaries (20\%). $8.5 \%$ girls had ovarian cyst.

Table 3: Dual client approach.

\begin{tabular}{|lll|}
\hline $\begin{array}{l}\text { Girls were accompanied } \\
\text { by their mothers }\end{array}$ & $342(85.5 \%)$ & $\mathrm{N}=400$ \\
\hline $\begin{array}{l}\text { HPV vaccination given for } \\
\text { girls }\end{array}$ & $47(12 \%)$ & $\mathrm{N}=400$ \\
\hline Mothers pap smear & $178(52 \%)$ & $\mathrm{N}=342$ \\
\hline
\end{tabular}

\section{DISCUSSION}

In our study the most common gynaecological problem was menstrual disorders seen in $70 \%$ of the girls. Dysmenorrhea was present in more than $50 \%$ of girls. Pain abdomen was present in $21 \%$ of girls and vaginal discharge was seen in $20 \%$ of girls. $23 \%$ had come for queries regarding their menstrual health and concern for weight gain, excessive fall of hair. AUB was seen in $12 \%$ of cases. Abnormal BMI was seen in $32 \%$ of girls. In study by Samarth S et al $9.86 \%$ had menorrhagia, $11.52 \%$ girls had evidence of polycystic ovaries.7Study by Gedam JK had most common menstrual problems being dysmenorrhea and primary amenorrhea in $1.57 \%$ of cases similar to our study. ${ }^{8}$

In our study anaemia was seen in $40 \%$ of girls, 17 girls had hemoglobin \% less than $7 \mathrm{~g} \%$. Serum $\mathrm{TSH}$ was normal in $89 \%$ of girls. Anaemia was observed in $57.84 \%$ of girls in study by Gedam JK. ${ }^{8}$ Menstrual abnormalities are the most common problems of adolescent girls. . $^{3,9-12}$ Thaker RV et al, study had common menstrual problem being dysmenorrhea in $52.9 \%$ of cases similar to our study followed by menstrual irregularities. ${ }^{13}$ Goswami Sebanti et al and Bhalerao-Gandhi A et al study had most common problem being menstrual problem followed by leucorrhoea same as our study.,14

\section{CONCLUSION}

Teenage problems need to be dealt very sensitively. Counseling is an integral component of treatment strategies. At present, adolescent gynaecology remains an area to which increased awareness and greater attention should be given to promote the health of teenagers and incult healthy lifestyle practices. In the same set up even the mothers of girls can be given counseling and address their gynecological issues as majority of times mothers are the accompanying person creating the dual client approach in one setting. Hence adolescent clinic should aim for holistic, dual client approach for improvement of overall women health in the family.

Funding: No funding sources Conflict of interest: None declared

Ethical approval: Not required 


\section{REFERENCES}

1. Hertweck P, Yoost J. Common problems in pediatric and adolescent gynecology. Expert Review Obstet Gynecol. 2010;5(3):311-28.

2. Karki C, Shrestha NS, Rayamajhi RT. Gynecological disorders of adolescent girls at Kathmandu Medical College Teaching Hospital. NJOG. 2008;3(2):44-7.

3. Goswami S, Dutta R, Sengupta S. A profile of adolescent girls with gynecological problems. J Obstet Gynecol India. 2005;55(4):353-5.

4. Gilliam M. Gynecologic problems of adolescence and puberty. Glob Libr Women's Med. (ISSN: 17562228) 2011; doi:10.3843 /GLOWM.10013.

5. Bhalerao-Gandhi A, Vaidya R, Bandi F. Managing gynecological problems in Indian adolescent girls-a challenge of 21st century. Obstet Gynecol Int $\mathrm{J}$. 2015;3(1):00070.

6. Ghongdemath JS, Sidhmalswamy A, Mallapur AA, Shindholimath VV. Impact of adolescent health education on adolescent girls in rural schools and colleges. Int J Reprod Contracept Obstet Gynecol. 2016;5(1):53-7.

7. Samarth S, Inamdar S, Hariharan C, Kalyani KR. Study of various gynaecological problems and reproductive health awareness amongst adolescents at a rural setup in central India. Int $\mathbf{J}$ Reprod Contracept Obstet Gynecol. 2014;3(4):1010-4.

8. Gedam JK. Study of reproductive health problems in adolescent girls at ESIC PGIMSR, MGM Hospital,
Parel, Mumbai: a retrospective study. Int J Reprod Contracept Obstet Gynecol. 2017;6:4285-90.

9. Lalitha S, Ramalingappa P. Adolescent girl - the gordian knot. The New Indian J Obgyn. 2019;5(2):131-5.

10. Ramaraju HE, Shivakumar HC, Khazi A. Adolescent gynaecological problems in a tertiary care centre. Indian J Basic Applied Med Res. 2015;4(4):649-53.

11. Revathi, Karunavathi GPN, Srilakshmi. Adolescence gynecological problems and legal acts. IOSR J Dent Med Sci. 2015;14(3):25-8.

12. Kumari A. Adolescent gynaecological problems: a clinical study. J Evolut Med Dent Sci. 2013;2(9):1111-5.

13. Thaker RV, Madiya AB, Chaudhari HD, Maru JD, Baranda SB. Health profile of adolescent girls visiting obstetrics and gynecology department of tertiary care hospital. Int J Reprod Contracept Obstet Gynecol. 2018;7:4678-83.

14. Rathod AD, Chavan RP, Pajai SP, Bhagat V, Thool P. Gynecological problems of adolescent girls attending outpatient department at tertiary care center with evaluation of cases of puberty menorrhagia requiring hospitalization. J Obstet Gynecol India. 2016;66(S1):S400-S406.

Cite this article as: Shetty VH. Study of adolescent clinic: holistic approach for women health with dual client methodology. Int J Reprod Contracept Obstet Gynecol 2019;8:3671-4. 